\title{
The evaluation of opinions and attitudes of dentists towards the use of rubber dam during operative and endodontic procedures
}

\author{
Azhar Iqbal $^{1}$ \\ ${ }^{I}$ Department of Conservative Dentistry, College of Dentistry, University of Aljouf, Saudi Arabia
}

\begin{abstract}
The objective of this study was to evaluate the opinions and attitudes of dentists toward the use of rubber dam during various restorative procedures in their dental practices. A structured questionnaire was designed, and distributed to 300 dentists and those that were fully completed were collected for analysis. The collected informations about the opinions and attitudes of dentists toward the use of rubber dam were statistically analyzed in terms of percentages and frequencies using a computer software SPSS version10. Out of 200 hundred respondents 178 (89\%) do amalgam restorations and out of those 50\% never used rubber dam and $13 \%$ always used the rubber dam. $96.5 \%$ do direct anterior composite restorations, out of those $63.7 \%$ never used the rubber dam whereas $18 \%$ always used the rubber dam. $94.5 \%$ do direct posterior composite restorations, out of those $65.6 \%$ never used the rubber dam and $11.6 \%$ always used the rubber dam. $76 \%$ do the endodontic treatment, out of those $36 \%$ never used the rubber dam and $26.9 \%$ always used the rubber dam.

Keywords: Attitude, Dental practice, Endodontics, Operative, Rubber dam
\end{abstract}

\section{Introduction}

The rubber dam has been considered as a standard of care during operative and endodontic procedures, because of its many advantages. ${ }^{1,2}$ Rubber dam provides an infection control barrier during the dental procedures by reducing the bacterial contamination of any dental preparation and root canal system. ${ }^{3,4}$ It also provides an infection control barrier for the dentists and patients by preventing the transmission of any infectious agent between them. It improves the efficency of treatment during root canal treatment. ${ }^{5,6}$ The choice of irrigant is strongly dependant upon the use of rubber dam during endodontic treatment. It has been reported by $71 \%$ of the rubber dam user, that they are using recommended sodium hypochlorite as root canal irrigant, as compared to only $38 \%$ for non rubber dam users. As rubber dam acts as a protective shield in the working area, therefore it protects inhalation and swallowing of dental materials, fine instruments, tooth fragments and irrigants into the patient's orophyranx. ${ }^{7,8}$ Many societies in the world recommend the use of rubber dam in many dental procedures, including the European Society of Endodontology ${ }^{9}$ and British Society of Paediatrics Dentistry. But inspite of all the known advantages of rubber dam, the majority of dentists do not always use a rubber dam during operative and endodontic procedures. ${ }^{9,10}$ The main reasons for not using the rubber dam are challenging technique, time consuming, patient's non compliance, cost of equipment and materials ${ }^{5,10,11,12,13}$, insufficient training of dentists and patient discomfort. ${ }^{14,15}$ Gowing and Sawinski ${ }^{16}$ reported that the use of rubber dam was low in the United Kingdom and North America, while Jenkins et al ${ }^{17}$ reported that rubber dam was not routienly used, even for the root canal treatment. About $5 \%$ of the dentists in the National Health Services of UK were reported to use rubber dam more than their colleagues in private practice. ${ }^{18}$ Marshall and Page ${ }^{19}$ reported that rubber dam was used in $1.4 \%$ of operative procedures in the UK, as compared with $10.9 \%$ of endodontic procedures. Many studies have been conducted, in several countries to quantify the use of rubber dam during endodontic and operative procedures. ${ }^{20,21}$ These studies have shown that prevalence of rubber dam use during endodontic procedure was low ${ }^{20,21}$. Similarly the reported use of rubber dam for the operative procedures was much lower as shown by questionnaire based surveys and different clinical studies. ${ }^{22}$ Although there is an increasing awareness about the effective and evidence based dental practice, but still some clinical techniques such as rubber dam use during different restorative procedure is low and it has been rarely evaluated in Saudi Arabia. The main objective of this study was to evaluate the attitudes of dentists in the northern region of Saudi Arabia toward use of rubber dam during various restorative procedures in their dental practices.

\section{Materials and Methods}

A self administered structured questionnaire containing the items about the opinions and attitudes of dentists toward the use of rubber dam, was designed. Then this questionnaire was piloted and distributed to 300 dentists, and informations about the opinions and attitudes of dentists toward the use of rubber dam were collected. The collected informations were statistically analyzed in terms of percentages and frequencies using a computer software SPSS version 10. 


\section{Results}

Out of 300 surveyed dentists only 200 dentists $(66 \%)$ responded with completely filled questionnaires. Out of these 200 respondents, $152(76 \%)$ were general dentists and $48(24 \%)$ were operative dentists and endodontists. Out of 200 hundred respondents 178 ( $89 \%$ ) do amalgam restorations and out of those $50 \%$ never used the rubber dam and $13 \%$ always used the rubber dam. $96.5 \%$ do direct anterior composite restorations, out of those $63.7 \%$ never used the rubber dam whereas $18 \%$ always used the rubber dam. $94.5 \%$ do direct posterior composite restorations, out of those $65.6 \%$ never used the rubber dam and $11.6 \%$ always used the rubber dam. $76 \%$ do the endodontic treatment, out of those $36 \%$ never used the rubber dam and $26.9 \%$ always used the rubber dam. Table 1 gives the responses between "never" and "always." $62.5 \%$ of the respondents reported that their dental school training was adequate. $52.5 \%$ of the respondents reported that the use of rubber dam do influence the quality of restorative treatment but majority of the dentists did not always use rubber dam for restorative and endodontic treatment. The most common reasons for not using the rubber dam were patient discomfort or inconvinence $36 \%$, time consuming $25.5 \%$, unnecessary $12.5 \%$, patient uncompliance $11.5 \%$, latex allergy $8 \%$ and only $6.5 \%$ of the respondent reported that they do not use the rubber dam because of the cost.

\section{Discussion:}

In the present study the $66 \%$ response rate showed that it is the true representation of the opinions and attitudes of the dentists toward the use of rubber dam in northern region of Saudi Arabia. The results of present study are very much similar to the results of other international studies. ${ }^{2,14,19}$ The present study showed that, the use of rubber dam in both operative and endodontic procedures was quite low despite the known advantages of rubber dam. The majority of the respondents ie $96.5 \%$ in the present study, were placing direct anterior composite restorations, $94.5 \%$ placed direct posterior composite restorations, $89 \%$ of the respondents in the present study reported that they placed amalgam restorations and $76 \%$ of the respondents reported that they were doing endodontic treatment. But their responses of $77.5 \%, 80.7 \%, 78 \%$ and $45.8 \%$ by combining the responses in rank 1 and rank 2 in ( Table1), "never and seldom" showed that they never or seldom used a rubber dam when placing amalgam restorations, direct anterior composite restorations, direct posterior composite restorations and when performing endodontic treatment respectively. These responses are very similar in numbers for the same procedures i.e $76 \%, 66 \%, 61 \%$ and $53.5 \%$ in a survey conducted in $1985 .{ }^{23}$ $62.5 \%$ of the respondents reported that they were adequately trained in the use of rubber dam, but still they were not using rubber dam routinely in their dental practice, because in their opinion, they could achieve the proper isolation, without the use of rubber dam. The safety of the patients is one of the reasons for using rubber dam. Sometimes placing a new restoration requires the removal of an old amalgam restoration. Berglund and Molin found that the use of rubber dam reduces the plasma level of mercury of patient significantly that occurs after the procedure. ${ }^{24}$ To prevent frequently occurring subcutaneous air emphysema in elderly patients, Chan et al recommended the use of rubber dam when restoring Class v lesions. The chances of swallowing or aspiration of residual amalgam, resin, wedges, pins and burs during operative treatment and endodontic files during endodontic treatment can be reduced by the use of rubber dam, therefore the use of rubber dam is considered to be a standard of care in this and many other countries. ${ }^{19,25}$ The results of present study, by combining the responses in rank 1 and 2 in (Table1), "never and seldom", showed that almost $50 \%$ of the respondents do not use the rubber dam during endodontic treatment. Because they considered that the success rate of root canal fillings placed without rubber dam and with rubber dam was the same. Van Nieuwenhysen et $\mathrm{al}^{26}$, in a retrosepective clinical study, the influence of various factors on the outcome of retreatment cases, found that the outcomes of the retreatment cases were significantly better in those cases which were isolated with rubber dam. Abbott $(1994)^{15}$ evaluated 100 referred patients, who complained of continuing pain after commencement of root canal treatment. Of all the factors which were considered responsible for pain, the lack of use of rubber dam revealed the first and it was observed in $87 \%$ of the patients. Sodium hypochlorite $(\mathrm{NaOCl})$ is considered one of the best root canal irrigants, because of its broad antimicrobial spectrum and unique capacity of destroying the necrotic tissue remanants. ${ }^{27}$ But despite these advantages, it is highly irritant, therefore it should be only used when rubber dam is in place. The use of rubber dam during endodontic treatment has a strong influence on the choice of root canal irrigant. ${ }^{28}$ Frequent users of rubber dam were more likely to use $\mathrm{NaOCl}$ in higher concentrations than those who used more bland solutions like saline and local anaesthetics. ${ }^{29}$ The use of rubber dam is considered the minimal level of safety during the endodontic treatment. ${ }^{9,30}$ The importance of safety of rubber dam is highlighted by the list of endodontic instruments that have been ingested or inhaled. ${ }^{7}$ The record of two insurance companies were examined by Susini et al. ${ }^{8}$ This represented 24,651 French dentists over 11 years period and found that the incidence of aspiration or ingestion of endodontic instruments was quite low i.e 0.001 per 100,000 and 0.12 per100,000 root canal treatments respectively. Despite this, doing root canal treatment without the use of rubber dam is harmful for the patient and it is considered legally indefensible. ${ }^{9,30}$ Chan et al in his study, evaluated the rubber dam as an infection control barrier during standard restorative 
procedures. It was found that the rubber dam acted as a surgical drape and isolated the operating field from microbial contamination as the primary source and thereby protected the patients as well as treating dentists. Rubber dam has been very extensively researched and universally advocated technique and majority of the dentists have been trained in its placement in their undergraduate courses, yet they do not employ it when they begin their professional practice. This shows that the use of rubber dam within and outside the dental school is not because of insufficient training but as a result of less emphasis on the rationale of using rubber dam and its relevance to the practice of modern dentistry. ${ }^{31,32}$ The main reasons for not using rubber dam by the responding dentists in present survey were patient's discomfort $36 \%$ and insufficient time $25.5 \%$. But patient discomfort may not be a valid reason as the survey was conducted among the dentists rather than patients, and therefore it could be the dentist's view. The best way to improve the patient's acceptance of rubber dam is that the operator should use the rubber dam frequently and thus become proficient. ${ }^{31}$ The successful and efficient placement of the rubber dam comes with experience, which requires regular use of rubber dam. Therefore the underutilization of the rubber dam during endodontic and operative procedures, may be due to lack of proficiency of dentists rather than lack of knowledge and insufficient training. ${ }^{2}$ In the present study, $25.5 \%$ of the respondents stated that additional time, taken for the placement of rubber dam was another reason for not using the rubber dam. However literature shows that even a very inexperienced dentist can apply the rubber dam in a few minutes. ${ }^{33}$ Furthermore, it has been suggested in literature that extra time spent in placing the rubber dam is compensated with better working conditions as offered by using rubber dam including to eliminate the need for changing cotton rolls frequently, control of saliva contamination, and reducing the movements of the patient's lip and tongue. The studies have shown that rubber dam may reduce the incidence of post treatment disease during the root canal treatment. ${ }^{34}$

\section{Conclusion}

Majority of the responding dentists in the present study believe that the use of rubber dam has a positive effect on the quality of restorative treatment delivered to the patients. Furthermore, majority of the responding dentists in the present study stated that their undergraduate training was adequate in the use of rubber dam. Despite these facts, the rubber dam was underutilized technique during different restorative procedures by the responding dentists in the present study. Therefore the results of our study conclude that there is a need to increase the awareness about the use of rubber dam among the dentists of northern region of Saudi Arabia to improve the quality of restorative treatment delievered, to improve the infection control for the patients and dentists, to incease the patient's safety from the procedural accidents and to avoid the dentists from medicolegal issues. We recommend that professional bodies should increase the awareness about the use of rubber dam among the dentists through different awareness campaigns using print and electronic media and through the conduction of continuing education courses.

\section{References}

[1]. Ahmad IA. Rubber dam usage for endodontic treatment: A review. Int Endod J 2009;42:963-72.

[2]. Lynch CD, McConnell RJ. Attitudes and use of rubber dam by Irish general dental practitioners. Int Endod J 2007;40:427-32.

[3]. Samaranayake LP, Reid J, Evans D. The efficacy of rubber dam isolation in reducing atmospheric bacterial contamination. ASDC J Dent Child 1989;56:442-4

[4]. Sjogren U, Figdor D, Persson S, Sundqvist G. Influence of infection at the time of root filling on the outcome of endodontic treatment of teeth with apical periodontitis. Int Endod J 1997;30:297-306.

[5]. Whitten BH, Gardiner DL, Jeansonne BG, Lemon RR. Current trends in endodontic treatment, report of a national survey. J Am Dent Assoc 1996; 127;1333-1341.

[6]. Slaus G, Bottenberg P. Asurvey of endodontic practice amongst Flemish dentists. Int Endod J 2002;35;759-767.

[7]. Kuo SC, Chen YL. Accidental swallowing of an endodontic file. Int Endod J 2008,41;7:617-22.

[8]. Susini G, Pommel L, Camps J. Accidental ingestion and aspiration of root canal instruments and other dental foreign bodies in a French population. Int Endod J 2007;40;8:585-9.

[9]. Peters OA, Peters FC. Ethical principles and considerations in endodontic treatment. ENDO ( Lond Engl) Endodontic Practice Today 2007;1:101-108.

[10]. Faculty of General Dental Practioners ( UK ). Clinical Standards in General Dental Practice: Self-Assessment Manual and Standards. London: Faculty of General Dental Practioners, Royal College of Surgeons of England 1991.

[11]. Cohen SC. Endodontics and litigation: an American perspective. Int Dent J 1989;39:13-16.

[12]. Jokinen MA, Kotilainen R, Poikkeus P, Poikkeus R, Sarkki L. Clinical and radiographic study of pulpectomy and root canal therapy. Scand J Dent Rest 1978;86:366-373.

[13]. Kerekes K, Tronstad L. Long-term results of endodontic treatment performed with a standardized technique. J Endo 1979;5:83-90.

[14]. Udoye CI, Jafarzadeh H. Rubber dam use among a subpopulation of Nigerian dentists. J Oral Sci 2010;52:245-9.

[15]. Abbott PV. Factors associated with continuing pain in endodontics. Aust Dent J 1994;39:157-61.

[16]. Going RE, Sawinski VJ (1968) Parameters related to the use of the rubber dam. J Am Dent Assoc 77,598-601.

[17]. Jenkins SM, Hayes SJ, Dummer PM (2001) A study of endodontic treatment carried out in dental practice within the UK. Int Endod J 34, 16-22.

[18]. Silversin B, Shafer M, Sheiham A, Smales FC (1975) The teaching and practice of some clinical aspects of endodontics in Great Britain. J Dent 3,77-80.

[19]. Marshall K, Page J. Use of rubber dam in the UK. A survey. Br Dent J 1990;169:286-91. 
[20]. Al-Fouzan KS. A survey of root canal treatment of molar teeth by general dental practioners in private practice in Saudi Arabia. Saudi Dent J 2010;22:113-17.

[21]. Whitworth JM, Seccombe GV, Shoker K, Steele JG. Use of rubber dam and irrigant selection in UK general dental practice. Int Endod J 2000;33:435-41.

[22]. Gilbert GH, Litaker MS, Philstrom DJ, Amundson CW, Gordan VV. Rubber dam use during routine operative dentistry procedures: Findings from the dental PBRN. Oper Dent 2010;35:491-99.

[23]. Joynt RB, Davis El, Schreier PH. Rubber dam usage among practicing dentists. Oper Dent 1989;14(4):176-81.

[24]. Berglund A, Molin M. Mercury levels in plasma and urine after removal of amalgam restorations: the effect of using rubber dams. Dent Mater 1991;13(5):297-304.

[25]. Hill EE, Rubel B. A practical review of prevention and management of ingested/aspirated dental items. Gen Dent, in press.

[26]. Van Nieuwenhysen JP, Aouar M, Dhoore W. Retreatmentor radiographic monitoring in endodontics. Int Endod J 1994;27:75-81.

[27]. Zender M. Root canal irrigants. J Endod 2006;32:389-98.

[28]. Koshy S, Chandler NP. Use of rubber dam and its association with other endodontic procedures in New Zealand. N Z Dent $\mathbf{J}$ 2002;98:12-6

[29]. Stewardson DA. Endodontics and the new graduates:Part I, practice vs training. Eur J Prosthodont Restor Dent 2002;10:131-7.

[30]. Cohen S, Schwartz S. Endodontic complications and the law. J Endod 1987;13:191 -7.

[31]. Stewartson DA, McHugh ES. Patient attitudes to rubber dam. Int Endod J 2002;35:812-9.

[32]. Swallow JN. Dental Practice in Northern Ireland, UK. Community Dent Oral epidemiol 1983;11:169-73.

[33]. Ryan W, O'Connell A. Attitudes of undergraduate dental students to the use of rubber dam. J Ir Dent Assoc 2007;53:87-91.

[34]. Sjogren U, Hagglund B, Sundqvist G, Wing K. Factors affecting the long term results of endodontic treatment. J Endod $1990 ; 16: 498-503$

Table 1: Attitude of dentists towards the use of rubber dam in dental practice

\begin{tabular}{|c|c|c|c|c|c|c|c|}
\hline \multicolumn{3}{|c|}{ Do you perform or place } & \multicolumn{4}{|c|}{ Use of rubber dam } & \multirow[b]{2}{*}{$\begin{array}{c}\text { Always } \\
5 \\
\end{array}$} \\
\hline $\begin{array}{l}\text { Type of } \\
\text { restoration }\end{array}$ & Yes & No & $\begin{array}{c}\text { Never } \\
1\end{array}$ & $\begin{array}{l}\text { Seldom } \\
2\end{array}$ & $\begin{array}{c}\text { Ocassionally } \\
3\end{array}$ & $\begin{array}{c}\text { Often } \\
4\end{array}$ & \\
\hline Amalgam & $\begin{array}{c}178 \\
(89 \%)\end{array}$ & $\begin{array}{c}22 \\
(11 \%)\end{array}$ & $\begin{array}{c}98 \\
(50 \%)\end{array}$ & $\begin{array}{c}49 \\
(27.5 \%)\end{array}$ & $\begin{array}{c}13 \\
(7.3 \%)\end{array}$ & $\begin{array}{l}5 \\
(2.3 \%)\end{array}$ & $\begin{array}{c}13 \\
(7 \%)\end{array}$ \\
\hline $\begin{array}{l}\text { Direct anterior } \\
\text { composite } \\
\text { restorations }\end{array}$ & $\begin{array}{c}193 \\
(96.5 \%)\end{array}$ & $\begin{array}{c}7 \\
(3.5 \%)\end{array}$ & $\begin{array}{c}123 \\
(63.7 \%)\end{array}$ & $\begin{array}{c}33 \\
(17 \%)\end{array}$ & $\begin{array}{l}13 \\
(6.7 \%)\end{array}$ & $\begin{array}{c}6 \\
(3.1 \%)\end{array}$ & $\begin{array}{l}18 \\
(9.3 \%)\end{array}$ \\
\hline $\begin{array}{l}\text { Direct posterior } \\
\text { composite } \\
\text { restorations }\end{array}$ & $\begin{array}{c}189 \\
(94.5 \%)\end{array}$ & $\begin{array}{c}11 \\
(5.5 \%)\end{array}$ & $\begin{array}{c}124 \\
(65.6 \%)\end{array}$ & $\begin{array}{c}25 \\
(13.2 \%)\end{array}$ & $\begin{array}{l}17 \\
(8.9 \%)\end{array}$ & $\begin{array}{c}11 \\
(5.8 \%)\end{array}$ & $\begin{array}{c}22 \\
(11.6 \%)\end{array}$ \\
\hline Endodontics & $\begin{array}{l}152 \\
(76 \%)\end{array}$ & $\begin{array}{c}48 \\
(24 \%)\end{array}$ & $\begin{array}{c}55 \\
(36 \%)\end{array}$ & $\begin{array}{c}15 \\
(9.8 \%)\end{array}$ & $\begin{array}{c}19 \\
(12.5 \%)\end{array}$ & $\begin{array}{l}22 \\
(14.4 \%)\end{array}$ & $\begin{array}{c}41 \\
(26.9 \%)\end{array}$ \\
\hline
\end{tabular}

What is your opinion about your dental school training in the use of rubber dam?

\begin{tabular}{|l|l|}
\hline Inadequate & Adequate \\
\hline $75(35 \%)$ & $125(62.5 \%)$ \\
\hline
\end{tabular}

\section{In your opinion what is the most common reason for not using the rubber dam?}

\begin{tabular}{|l|l|l|l|l|l|}
\hline Cost & Time & Patient discomfort & $\begin{array}{l}\text { Patient } \\
\text { uncompliance }\end{array}$ & Unnecessary & Latex allergy \\
\hline 13 & 51 & 72 & 23 & 25 & 16 \\
\hline $6.5 \%$ & $25.5 \%$ & $36 \%$ & $11.5 \%$ & $12.5 \%$ & $8 \%$ \\
\hline
\end{tabular}

\section{Does rubber dam has any effect on the quality of restorative treatment?}

\begin{tabular}{|c|c|}
\hline No & Yes \\
\hline $95(47.5 \%)$ & $105(52.5 \%)$ \\
\hline
\end{tabular}

